Biannual Research Journal Grassroots

Vol.55, No.II, 2021: 198-209

Grassroots

\title{
CHINA PAKISTAN ECONOMIC CORRIDOR: PERSPECTIVES AND CHALLENGES FOR IRAN
}

\author{
Dr Shah Nawaz Mangi \\ Department of Political Science, Government College University Hyderabad \\ Email: shahnawaz.mangi@gcuh.edu.pk \\ Dr Ayaz Ahmed Chachar \\ Assistant Professor Department of Public Administration, University of Sindh \\ Email: ayaz.chachar@usindh.edu.pk \\ Dr Sadia Khurram Shaikh \\ Assistant Professor, Benazir School of Business, \\ Benazir Bhutto Shaheed University, Karachi, Pakistan \\ Email: dr.sadiashaikh@,bbsul.edu.pk
}

\begin{abstract}
Regional as well as international media, think tanks, policy makers and social scientists are considering the regional economic giant, China-Pakistan Economic Corridor, as a game changer. Its strategic position has made it so not only for the states of Pakistan and China but also for the region. Alike other corridors, it aims to connect and enhance collective growth economically and socially. It is apparent that the corridor is a source of regional connectivity. Therefore, it may be useful in enhancing economic cooperation between Pakistan and Iran. The relations between both the states have remained cordial but due to the international pressure and regional interests, the volume of bilateral trade has reached to the lowest degree. Since 2014, the Pak-Iran trade has remained under US\$ 229 million annually. By using SWOT technique, present study finds that the inclusion of Iran in the corridor will be a turning point in its economic history. At present, Iran is facing worst kind of economic crisis due to international sanctions. It can recover her exports slowly by using CPEC route to India, China and Pakistan. Further, Iran can manage an equilibrium against Saudi Arabia's influence in the region.
\end{abstract}

Keywords: China Pakistan Corridor, Iran, Regional Integration

\section{INTRODUCTION}

Social scientists have assumed that $21^{\text {st }}$ century is the century of power shift. In this regard, a rapid change can be observed in almost every sphere of life across the globe. China is playing an essential role to shape this change. For this purpose, under President XI Jinping, China views developing countries of Asia as her potential economic 
partners. Therefore, the mighty concept of 'One Belt One Road' (OBOR) has taken place. With the implementation of this plan, China will be able to connect its most affordable routes to Russia, Middle East, Europe and Indian Ocean. One of the flagship projects of this mega plan (OBOR) is China Pakistan Economic Corridor (CPEC), that enables China to reach warm water of Arabian Ocean (Ahmad, 2017). It is considered that the geopolitical structure of South Asia will be changed through this project. CPEC develops sustained linkages among western Chinese zone, Pakistan and through Arabian Ocean to countries of the Middle East (Ahmad, 2016). The project mainly focuses on the development of infrastructure and fulfillment of the energy needs of Pakistan. Within fifteen years of time, the project will have to achieve its targets (Ali et.al., 2019).

\section{Approach to Corridor}

Corridors are the potential linkages between economic hubs which are mostly located in the urban and coastal areas (Basit, 2018). According to the African Development Bank, "corridor approach looks at regional transport routes not only as a means of transporting goods and services or as a gateway for land-locked countries, but also as a tool for stimulating social and economic development in the areas surrounding the route" (Belal, 2017). It is important to develop the infrastructure in such a way that curtails corridor's negative effects on eco-social system while increasing its positive impact on economic growth (Idrees, R. Q. et.al., 2018). Further, corridors are usually a package of various developmental projects, such as infrastructure (that includes modes of transportation, like roads, railways), energy and development of economic zones (Butt\& Butt, 2015). With the developments of all these sectors, quality of life can be made better due to the provision of upgraded social services. Some of the major characteristics of economic corridor are as follow:

a) Along a major route, corridor covers a particular geographic area.

b) It is so often that corridor is a package of bilateral projects.

c) It mainly focuses on the up gradation of infrastructure to provide better opportunities to its neighboring areas. 
Despite the fact that no universally accepted model of economic corridor is present and literature lacks the proper method of its achievement, it is argued that it does not work alone because of the role it plays in regional connectivity. Regional interoperability, effective management, integration and development that is based on harmony can be achieved through corridor (Hafiz, 2017). The achievements of economic corridor in term of regional integration mainly depends on two factors: firstly, particular characters of the existing network where the corridor is going to be implemented and secondly, intentions on which the corridor is planned (Hafiz, 2018).

While knowing the importance of corridor for Pakistan as well as for the region, the current study endeavours to analyze the impact of corridor on Iran and highlights how the project is beneficial for it?

To find out the answer of the question mentioned above, secondary data has been examined by applying SWOT technique (Figure-1). The technique is considered as one of the important tools in order to monitor a running project or develop a new. It is helpful in examining the multidimensional factors, minimize the after-effects and maximize the benefits. With the help of the technique, the study is subdivided into certain section, every section is providing clear insight of the domain. The division will help to identify the strengths and minimize the weaknesses of the project in the context of Iran. Further, expected opportunities and eradication of the threats will also be examined. The study is rare in its kind that investigates the impact and opportunities of CPEC for Iran by applying SWOT method.

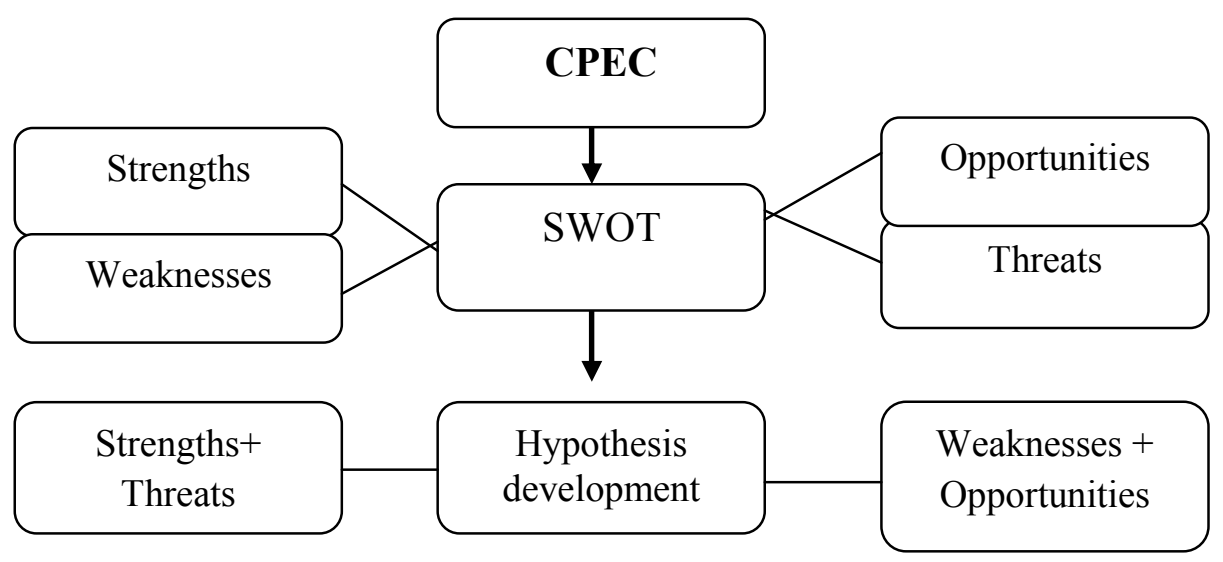

FIGURE-1: CONCEPTUAL MODEL 


\section{ANALYSIS AND FINDINGS}

\section{i) STRENGTHS}

Geographic Location: The project occupies a significant strategic position on the map of world. China, the rising power of the world is located at its northeastern side while energy-rich Iran is situated at the southwest of the project. The policymakers in Pakistan seem to understand that elixir to regional security catastrophe as well as the country's weak economy is making friends in the region. Under these conditions, China is contemplated as a time-tested friend while both Pakistan and Iran have not yet taken the advantages of their potential as a partner, despite of geographic, religious and cultural linkages. The magnitude of bilateral trade has remained low between both the countries due to the domestic, regional and international pressures. However, a nexus of three can be formulated by working together. This is likely to enhance their collaboration and economic strength.

Fulfilling National Interest: For Pakistan, the project is not only a foreign investment but a balance of power against highly increasing military might of India in the region. For China, the project provides the opportunity to reach Arabian Ocean through shortest possible routes. Furthermore, for the landlocked countries such as, Turkmenistan, Uzbekistan, Tajikistan and Afghanistan, it is a ripe opportunity to get access to the international market by an economic means. It is apparent that the corridor is a source of regional connectivity (Amir, 2017). Therefore, it will be useful in enhancing economic cooperation between Pakistan and Iran. The relations between both of these states have remained cordial but due to international pressure and regional interests, the volume of bilateral trade has reached to the lowest degree. Since 2014, the trade between these countries has remained under US\$ 229 million annually (Ansar, 2017). Under these circumstances, fruitful results can be achieved by working together.

Economic Integration in the Region: When countries reach an agreement by setting down common objectives, it is called regional integration. The agreement or mutual understanding may be developed on political, socio-cultural, environmental or security grounds but more often it is observed on economic grounds. Economic integration in the region includes the eradication of tariffs or security barriers for 
cross regional countries in order to enhance inter-regional trade (Wadood, 2019). The network of regional integration is depicted by the activities, such as macro policies, labour mobility, trade and so forth while its depth depends on the level of sovereignty that a state is willing to surrender (Hussain, E., 2019). Despite the shrinking degree of sovereignty, a state can achieve high level of benefits from regional integration. When a peaceful solution is perceived through regional integration, it can be helpful in arranging the region to reap social, political and environmental benefits.

Enhancing Geopolitical Cooperation: As it is close to the fact that the regions like Middle East, South Asia and East Asia hold important strategic positions in world politics. The geographic position, markets and conflicts in these regions have wide ranging and serious implications on the rest of countries. All of these regions are being connected with one another through the project.

The present study is limited to analyze the impact of this nexus on Afghanistan and India.

\section{Afghanistan Factor}

Evading every effort to bring peace in Afghanistan, the conflict in the country is being considered as an anathema by regional as well as global players. The national security of Pakistan has been facing serious challenges due to the uncertain and unstable conditions of Afghanistan. Similarly, turbulent circumstances in Afghanistan negatively affect the economic developments in China and Iran.

In the past, the individual interest of these countries in Afghanistan were different but at present every party desires a peaceful and stable Afghanistan. External influence in Afghanistan (US and India) is opposed by all these countries. Therefore, individual interests of these countries align them which ultimately increase the chances of geopolitical cooperation.

\section{Indian Factor}

Alike China, India is also an emerging power of Asian continent. An economic and militarization race has been witnessed between the two countries for long. CPEC offset the Indian claim to be the regional leader by connecting China to Iran, Afghanistan and UAE, the 
connectivity which India is lacking. Further, the project enables Chinese naval power to be dominant in Arabian and Indian oceans.

Similarly, India assumes "economically prosperous Pakistan much dangerous than nuclear Pakistan".

\section{ii) WEAKNESS}

Dysfunctional relations Between Iran and Pakistan: Since Iranian revolution (1979), the relations between the two countries have remained up and down, if not complicated. Both the states worked for the betterment and stability in Afghanistan but at the same time they did not bother to see eye-to-eye regarding the role of Taliban. Repeated slaughtering of Shiites in Pakistan and cross boarder terrorism in Baluchistan serve as irritants in the relations most often. Similarly, Indian role in Iran and Pakistan's relations with Saudi Arabia are the major cause that enhances the level of distrust when it comes to bilateral relations.

Political Uncertainty: The host country of the project (Pakistan) after celebrating more than seventy years down to the road is still at the crossroad when it comes to institutional balance, political stability and rule of law. The country has suffered due to the conflict between three major players: civil-military bureaucracy, political forces and Islamic groups. The conflict between these forces has caused a serious damage to the country's diplomatic stature at global and instability in political system at domestic level. Authority of the state or political system adversely is affected by these confronting forces in the long run.

\section{OPPORTUNITIES AND THREATS}

i) Opportunities

Co-existence: It is argued by the liberal theorists that armed conflicts can be reduced through economic interdependence. The argument is also supported by the 'Economic opportunity cost Hypothesis' theory (Khan, 2016). Visionary leaders as well as policymakers emphasize their proclivities to find the peaceful solution of their conflicts with economically interdependent countries. The advantages or cost of the corridor linked with the trade deters states from participating in the war (Mangi, 2019). Likewise, countries which are not integrated economically have greater chances to wage wars because no cost is attached to their trade. Contrary, realists argue 
that decision to wage a war or not with any specific country is not based on economic interests but it is calculated with multidimensional approach by the decision makers (Rafique, 2016). Further, realists believe that armed conflicts are fueled on the basis of economic benefits. Neo-Functionalism Theory has the potential to describe regional integration. The theory was presented in $1950 \mathrm{~s}$ and it describes the role of supranational bodies in the integration of Europe. The idea of "spillover" was the major contribution of this theory (Wolf, 2018). According to the spillover concept, cooperation in one sector provides the opportunity to cooperate in another sector. Due to this concept, the theory remains under criticism because it did not explain protectionism and limitations as it describes automaticity in the process of integration.

In case of CPEC, both these theories (Economic Opportunity Cost Hypothesis and Neo-Functionalism Theory) are quite applicable when it comes to its expected impact on Iran (Umar, 2019). Both Pakistan and Iran are facing internal as well as external challenges. At the same time, the volume of trade between these countries is rapidly moving to its lowest degree. Similarly, border conflicts are observed usually, therefore, the level of distrust between these states is highly increasing (Wolf, S. O., 2020b). Thus, economic interdependence may provide opportunities to both states to resolve their problems peacefully.

Grounds for Iran's inclusion in SCO: Social scientists opine that energy insecurity as well as inadequacy will be among the most serious problems for the globe in the time to come. Unfortunately, Pakistan has already faced this challenge. The country is striving to overcome this challenge through CPEC. In addition, the country comes closer to achieving this goal by joining Shanghai Cooperation Organization (SCO) in 2017.

Since 2008, Iran has been trying to get the membership of SCO but denied so far. After the removal of sanctions, it seems that Iran is intending to revisit her policies, most probably she shifts from Indian camp to the Chinese. It will smoothen its way to be a full member in SCO. This will be a bright opportunity for partner countries to fulfill their national interests.

Continuity of "Look East Policy": The "conservative camp" in Iran considers China and Russia as potential allies because of their 
anti-America agenda. They argue that Iran must have powerful allies in the East to encounter American persistent pressure (Wolf, S. O., 2020a).

The two different approaches (opportunity centric and threat centric) somehow influenced political sphere in Iran related to China's Belt and Road project. However, when it comes to China specially, there are several factors except intellectual orientation and ideological that deviate the viewpoint of Iranian policy makers (Rahman, S. U., \& Shurong, Z., 2017). The rising power of China has given a strong base to 'opportunity centric' to take advantages of strategic opportunities (Ahmad, R., Mi, H., \& Fernald, L. W., 2020). As a policy, this view was adopted during the era of Ahmadinejad (2005-2013) in the form of "Look East" policy. This was an alternative of pro-Europe approach which was adopted by Akbar Hashemi Rafsanjani and Seyyed Mohammad Khatami (1989-2005). Top priority was given to Asian countries specially, China and Pakistan during Ahmadinejad's regime while relations with Western powers went into tension. Although the political administration was changed in 2013 but China still remains significant within the framework of 'Look East' policy of Iran (Awan, M. A., 2018). Advocates of 'opportunity centric' opine that opportunities for Iran are expanding with the increasing power of China in region as well as in the world system. Similarly, economic diplomats in Iran are also prioritizing China because of the access they were given in the markets of China during the period of sanctions (Hussain, E., 2020).

\section{ii) Threats}

Dark Future of Democracy: As described above that the two different and opposite opinions have been found in Iran regarding the CPEC project. These opinions are generally labeled as opportunity centric and threat centric. The project is being opposed by the "reformist" in Iran because of their old traditions attached with Western powers (Bahgat, G., 2016). This opposition is based on their viewpoint that cordial relation with communist Eastern states i.e. China and Russia would threaten the future of democracy in Iran. Therefore, their opposition to CPEC is not directly related to Pakistan but with China and trembling conditions of democracy in Iran. 
Unemployment: The "threat centric" camp views China's rising power as a threat for their sovereignty and identity. Although this threat can also be observed in the majority of the developing nations of the region but it is most common among the Iranian elite. Proponents of "threat centric" are emphasizing on the relations with European Union in order to balance the influence and presence of China. They argue that a huge number of local industries will be closed with the arrival of Chinese companies, which will increase the level of unemployment in Iran (Syed, J., 2020).

\section{ANALYZING STRENGTH AND THREAT}

The results of the SWOT technique highlights that the project posses more strength when compared to the threats. When it comes to strength, its strategic location seems to be more fascinating. Iran is one of the most important neighboring countries of Pakistan. Abundance of energy enables it to export petroleum, chemicals, cement and many other products. Adversely, it imports skilled labour, industrial supplies and consumers goods (Shafqat, S., 2017). India, United Arab Emirates, China, Turkey, Japan and South Korea are the biggest trading partner countries of Iran (Singh, S., \& Singh, B., 2019). Iran was among the major opponents of CPEC at the initial stage but now it has shown her interest in the corridor because of the regional connectivity. By connecting to the corridor, it can enhance her trade at the highest level. It not only benefits Iran but to the entire region. With these intensions towards Gawader, long awaiting Iran-Pakistan-India (IPI) pipeline projects could be redesigned to Iran-Pakistan-China (IPC) Pipeline. The positive proposition of Iran can provide stability to the region specially Afghanistan. Fast and secure trade route will likely to bring linkages between South Asia to Middle East when Iran, Turkey and Pakistan will be able to connect through train route. This proposed route will be helpful in connecting South Asia to Europe via Turkey. Besides economic gains, strategic significance of Iran's recent willingness to join the corridor cannot be ignored (Sultan, M. F., Omar, M., \& Imtiaz, R., 2019). Both Iran and Pakistan are considering China as a useful alternative of USA hegemony. Iran's willingness to join the economic giant can help Pakistan in so many ways. First, the reduced level of bilateral trade can be enhanced through Iran's inclusion in the project. Secondly, Iran can play a significant role to fulfill Pakistan's energy crisis. Thirdly, India's influence in Iran and 
Afghanistan can be reduced. At the same time, the inclusion in the corridor may be a turning point in Iran's economic history (Shaheen, W., et.al., 2020). At present, Iran is facing worst kind of economic crisis due to international sanctions. It can recover her exports slowly by using CPEC route to India, China and Pakistan. Further, Iran can manage an equilibrium against Saudi Arabia's influence in the region.

\section{WEAKNESS AND OPPORTUNITIES}

The analysis shows that the dysfunctional relations between Iran and Pakistan is the most crucial among all weaknesses possessed by the project. In addition, unstable political system of the host country is another weakness of the project. Adversely, the provision of opportunities are more in number, therefore, weaknesses can be overcome if these opportunities are availed.

\section{CONCLUSION}

The current study concludes that regional stability, security and public welfare strongly depend on their economic conditions which are correlated with their bilateral trade. Regional connectivity will provide substantial economic growth which can ultimately reduce political as well as border conflicts between two Muslim countries of the region. Further, USA interference as well as influence in the regional countries can be reduced to minimum level if China gets a chance to play its leading role.

As far as Iran's uncertain attitude towards the project is related, it is the result of conflict of opinion between various camps in Iran. In other words, these contradictory approaches are the by-product of China's economic initiatives and its effects on geo-economic as well as geopolitical position of the region generally and particularly on Iran.

\section{REFERENCES}

Ahmad, R., Mi, H., \& Fernald, L. W. (2020). Revisiting the potential security threats linked with the China-Pakistan Economic Corridor (CPEC). Journal of the International Council for Small Business, 1(1), 64-80.

Ahmad, S., \& Malik, A. H. (2017). China-Pakistan Economic Corridor: Impact on Regional Stability of South Asia. International Journal of Political Science and Development, 5, 192-202.

Ahmed, Ayaz. (2016). Pak-Iran Relations and Future Prospects for Trade. Defence Journal 20, No.5, 31. 
Ali, B., Shah, N., \& Mangi, S. (2019). Entrepreneurial Intention among Physical and Health Education Students in Public sector Universities of Pakistan. The Shield-Research Journal of Physical Education \& Sports Science., 12.

Amir, Faaiz. (2017). CPEC and Regional Integration. Pakistan Development Review 56, No. 4, 579-597.

Ansar, A. (2019). Will Pakistan Have to Choose Between Saudi Arabia and Iran?. Defence Journal, 22(6), 77-80.

Awan, M. A. (2018). Pakistan-Iran Geo-Political Environment and the Discourse of Relations (1947-2017): A Reappraisal. Pakistan Journal of History and Culture, 39(1).

Bahgat, G. (2016). Iran-Asia Energy Partnership: Economic and Strategic Implications. Journal of South Asian and Middle Eastern Studies, 39(4), 47-62.

Basit, S. (2018). Explaining the impact of militancy on Iran-Pakistan relations. Small Wars \& Insurgencies, 29(5-6), 1040-1064.

Belal, K. (2017). Pak-Iran Relations: Evolving Dynamics, Prospects and Approaches. Policy Perspectives: The Journal of the Institute of Policy Studies, 14(1), 83-104.

Butt, K. M., \& Butt, A. A. (2015). Impact of CPEC on Regional and ExtraRegional Actors. The Journal of Political Science, 33, 23.

Hafiz, A. (2017). Managing Iran. Defence Journal, 20(11), 20.

Hafiz, A. (2018). Pakistan-Iran Economic Potential \& TIPEC. Defence Journal, 21(9), 27-29.

Hussain, E. (2019). CPEC: Governance and security challenges-Implications for the Belt and Road Initiative. Chinese Political Science Review, 4(1), 135-147.

Hussain, E. (2020). CPEC and the Belt and Road Initiative: Economic Implications for the Greater Middle East. Asian Journal of Middle Eastern and Islamic Studies, 14(1), 35-50.

Idrees, R. Q., Shapiee, R., Ahamat, H., \& Hanwei, L. (2018). How Logistics Investment Arrangement is a Key Concern to China-Pakistan Economic Corridor (CPEC)? A Legal and Policy Analysis of CPEC Logistics Investment Model and Future Challenges for Pakistan. International Journal of Asian Social Science, 8(11), 10591067.

Khan, S. A., \& Marwat, Z. A. K. (2016). CPEC: Role in Regional Integration and Peace. South Asian Studies, 31(2), 103.

Mangi, S. N., Chachar, A. A., \& Shah, N. (2019). Quality of Governance in Pakistan: An Investigation through Public Trust in National Institutions. International Research Journal of Arts \& Humanities (IRJAH), 47(47).

Rafique, N. (2016). Prospects of Pakistan-Iran Relations: Post Nuclear Deal. Strategic Studies, 36(3). 
Rahman, S. U., \& Shurong, Z. (2017). Analysis of Chinese Economic and National Security Interests in China-Pakistan Economic Corridor (CPEC) under the Framework of One Belt One Road (OBOR) Initiative. Arts and Social Sciences Journal, 8(4), 1-7.

Shafqat, S. (2017). China's Rise: How Is It Impacting the Gulf, Iran, Pakistan and Beyond?. Asian Journal of Middle Eastern and Islamic Studies, 11(1), 15-36.

Shaheen, W., Ghaffar, A., Hussain, Z., \& Ali, M. (2020). Socio-Political and Financial Risk Analysis of Infrastructure Projects Linked with ChinaPakistan Economic Corridor. RMC Journal of Social Sciences and Humanities, 1(1), 34-43.

Singh, S., \& Singh, B. (2019). Geopolitics of ports: Factoring Iran in India's counterbalancing strategy for "Sino-Pak Axis". Journal of Eurasian Studies, 10(2), 169-182.

Sultan, M. F., Omar, M., \& Imtiaz, R. (2019). Analyzing prevalent internal challenges to china Pakistan economic corridor (CPEC) through public opinion. Journal of Economics and Sustainable Development, 10(7).

Syed, J. (2020). Security and the Belt and Road: A Critical Analysis of Threats to Chinese Nationals and Businesses in Pakistan. In China's Belt and Road Initiative in a Global Context (pp. 131-180). Palgrave Macmillan, Cham.

Umar, Z., Taj, S., \& Adnan, S. (2019). CPEC: Security Threats and Measures. The Dialogue, 14(1), 17-17.

Wadood, A., Khan, H. U., \& Ullah, U. (2019). Geo-politics of China in $21^{\text {st }}$ century: Case study of China Pakistan Economic Corridor (CPEC). Buitems Journal of Social Sciences and Humanities, 68.

Wolf, S. O. (2018). China-Pakistan Economic Corridor (CPEC): Regional Cooperation in the Wider South Asian Region. In China's Global Rebalancing and the New Silk Road (pp. 85-100). Springer, Singapore.

Wolf, S. O. (2020a). Challenges Towards the Implementation and Functioning of the CPEC. In The China-Pakistan Economic Corridor of the Belt and Road Initiative (pp. 93-123). Springer, Cham.

Wolf, S. O. (2020b). Development Versus Democracy? The CPEC and CivilMilitary Relations in Pakistan. In The China-Pakistan Economic Corridor of the Belt and Road Initiative (pp. 281-306). Springer, Cham. 